\title{
Stable HIV-1 envelope glycoprotein immune complexes as vaccine immunogens
}

\author{
Thijs van Montfort ${ }^{1 *}$, Mark Melchers ${ }^{1}$, Tony MM van Capel $^{2}$, Ester $C$ de Jong ${ }^{2}$, William A Paxton", \\ Rogier W Sanders ${ }^{1}$ \\ From Frontiers of Retrovirology 2011 \\ Amsterdam, The Netherlands. 3-5 October 2011
}

The development of an HIV-1 vaccine that elicits strong neutralizing antibody (nAb) and $\mathrm{T}$ cell responses is challenging. Classical vaccine strategies such as live attenuated vaccines are considered unsafe whereas envelope glycoprotein (Env)subunit vaccines induce low $\mathrm{nAb}$ titers that do not protect against HIV-1 infection. We showed previously that most HIV-1-antibody immune complexes (HIV-ICs) formed with either broadly nAbs or Abs derived from patient sera dissociate into free HIV-1 virions and $\mathrm{Ab}$ when captured by dendritic cells (DCs). Dissociation of HIV-ICs allows for transmission from DCs to $\mathrm{CD} 4^{+} \mathrm{T}$ target cells. $\mathrm{H}$ but more importantly it can hamper the activation of immune cells which is a hallmark of stable ICs. The natural role of ICs is enhancing uptake by DCs, DC activation, induction of antigen presentation and induction of $\mathrm{T}$ cell responses. Furthermore, ICs are captured by follicular DCs that activate the B cells for $\mathrm{Ab}$ production, $\mathrm{Ab}$ affinity maturation and ísotype switching. We explore stable Env-ICs as a vaccine candidate. To form stable Env-ICs we fused the Fc-region of immunoglobulins to trimeric gp140. Env-IC maintained a native Env conformation which was evaluated by ELISA with Env-specific Abs. Native PAGE analyses and size exclusion chromatography showed that Env-ICs formed trimers, but hexamers consisting of 2 Env trimers and 3 dimeric Fc-tails were also observed. The functionality of the Fc-tail was evaluated by immuno-precipitation of the Env-IC with protein-G couple beads. Capture of Env-IC by DCs was enhanced with $50 \%$ compared to wild-type Env. Moreover, Env-IC captured by DCs more efficiently activated gp120-specificT helper cells.

'Laboratory of Experimental Virology, Department of Medical Microbiology, Academic Medical Center of the University of Amsterdam, Amsterdam 1105AZ, The Netherlands

Full list of author information is available at the end of the article
Acknowledgements

This research was supported by the Dutch AIDS fund, grants \#2008013 and \#2009012.

\section{Author details}

'Laboratory of Experimental Virology, Department of Medical Microbiology, Academic Medical Center of the University of Amsterdam, Amsterdam 1105AZ, The Netherlands. ${ }^{2}$ Department of Cell Biology and Histology, Academic Medical Center, University of Amsterdam, Amsterdam 1105AZ, The Netherlands.

Published: 3 October 2011

\section{doi:10.1186/1742-4690-8-S2-P75}

Cite this article as: van Montfort et al: Stable HIV-1 envelope glycoprotein immune complexes as vaccine immunogens. Retrovirology 2011 8(Suppl 2):P75.
Submit your next manuscript to BioMed Central and take full advantage of:

- Convenient online submission

- Thorough peer review

- No space constraints or color figure charges

- Immediate publication on acceptance

- Inclusion in PubMed, CAS, Scopus and Google Scholar

- Research which is freely available for redistribution
() Biomed Central

\section{Biomed Central}

